\title{
Two New Cytotoxic Quinone Type Compounds from the Halotolerant Fungus Aspergillus variecolor
}

\author{
Wenliang Wang, Tianjiao Zhu, Hongwen Tao, Zhenyu Lu, Yuchun Fang, Qianqun Gu, \\ Weiming Zhu
}

Received: July 27, 2007 / Accepted: September 4, 2007

(C) Japan Antibiotics Research Association

\begin{abstract}
Two new quinone type compounds, variecolorquinones $\mathrm{A}(\mathbf{1})$ and $\mathrm{B}(\mathbf{2})$ together with eleven known related compounds $\mathbf{3} \sim \mathbf{1 3}$ have been isolated from the metabolites produced by the halotolerant fungal strain Aspergillus variecolor B-17. The structures of $\mathbf{1}$ and $\mathbf{2}$ were determined by spectroscopic methods. 1 exhibited selective cytotoxicity against A-549 cells with the $\mathrm{IC}_{50}$ values of $3.0 \mu \mathrm{M}$. 2 showed cytotoxicity against HL60 and P388 cells with the $\mathrm{IC}_{50}$ values of 1.3 and $3.7 \mu \mathrm{M}$, respectively.
\end{abstract}

Keywords variecolorquinone, cytotoxic, metabolite, quinone, halotolerant fungi

\section{Introduction}

It demonstrated that halotolerant marine fungal species have evolved unique metabolic mechanisms that are responsive to salt concentrations and marine-derived fungal metabolite production could have implications for drug discovery [1]. Besides marine samples, halotolerant fungal species had been isolated from other hypersaline environment such as salterns, salines and dried fish. But, to the best of our knowledge, there were only a few reports on secondary metabolites of halotolerant fungus in the literature [2 4]. In order to screen "talented strains" [5] to find structural novel and bioactive secondary metabolites,

W. Zhu, Q. Gu (Corresponding author), W. Wang, T. Zhu, H. Tao, Z. Lu, Y. Fang: Key Laboratory of Marine Drugs, Chinese Ministry of Education; School of Medicine and Pharmacy, Ocean University of China, Qingdao 266003, China, E-mail: weimingzhu@ouc.edu.cn,guqianq@ouc.edu.cn we continue to isolate and identify halotolerant microbes from both marine [6 13] and other salt environments. As a result, a halotolerant fungal strain, Aspergillus variecolor B-17, was isolated from the sediments collected in Jilantai salt field, Alashan, Inner Mongolia, China.

The crude extract of the mycelia of $A$. variecolor B-17 showed significant cytotoxicity against the mouse $c d c 2$ mutant cell line (tsFT210) and was subjected to flash column chromatography over silica gel, RP-18 and HPLC separation to afford two new quinone type compounds variecolorquinones A (1) and B (2), together with eleven known compounds, (2S)-2,3-dihydroxypropyl 1,6,8-trihydroxy-3-methyl-9,10-dioxoanthracene-2carboxylate (3) [14], emodin (4) [15], physcion (5) [15], questin (6) [15], questinol (7) [15], catenarin (8) [15], erythroglaucin (9) [16], rubrocristin (10) [16], fallacinol (11) [15], eurotinone (12) [17] and 2-methyleurotinone (13) [17] (Fig. 1), by a bioassay-guided isolation procedure.

\section{Materials and Methods}

\section{Strain}

The working strain Aspergillus variecolor B-17 was isolated from the sediments collected in Jilantai salt field, Alashan, Inner Mongolia, China. It was identified by Prof. Li Tian, the First Institute of Oceanography, SOA, Qingdao, China. Working strain was prepared on Potato Dextrose agar slants containing $10 \% \mathrm{NaCl}$ and stored at $4^{\circ} \mathrm{C}$.

\section{Fermentation}

The fungus was grown under static conditions at $30^{\circ} \mathrm{C}$ for 28 days in thirty $1000-\mathrm{ml}$ conical flasks containing the liquid medium ( $300 \mathrm{ml} /$ flask) composed of ( $\mathrm{g} /$ liter): glucose 
<smiles>[R]Oc1cc(O)cc2c1C(=O)c1c(cc(C)c(C(=O)OC[C@H](O)[C@H](C)O)c1O)C2=O</smiles>

Variecolorquinone A (1) $\quad \mathrm{R}=\mathrm{CH}_{3}$ (2S)-2,3-Dihydroxypropyl 1,6,8-trihydroxy-3-methyl9,10-dioxoanthracene-2-carboxylate (3) $\quad \mathrm{R}=\mathrm{H}$

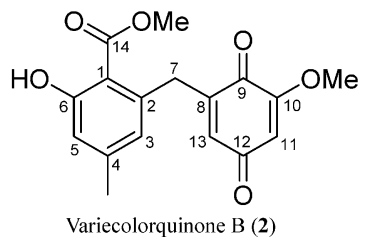<smiles>[R]Cc1cc(O)c2c(c1[R])C(=O)c1cc(O[R3])cc(O[R])c1C2=O</smiles>

Emodin (4) Physcion (5) Questin (6) Questinol (7) Catenarin (8) Erythroglaucin (9) Rubrocristin (10) Fallacinol (11)

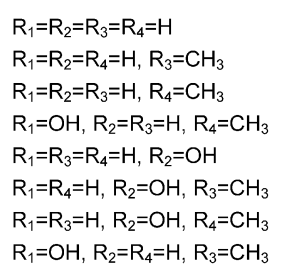

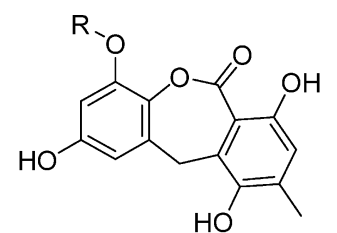

Eurotinone (12) 2-Methyleurotinone (13) $\quad \mathrm{R}=\mathrm{CH}_{3}$

Fig. 1 Structures of variecolorquinones A (1) and B (2), eleven known compounds $\mathbf{3} \sim \mathbf{1 3}$

(10), maltose (20), mannitol (20), malt extract (3.0), monosodium glutamate (10), $\mathrm{NaCl}(120), \mathrm{NH}_{4} \mathrm{Cl}(10)$, $\mathrm{MgSO}_{4} \cdot 7 \mathrm{H}_{2} \mathrm{O}(5.0)$ and $\mathrm{KCl}$ (5.0) after adjusting its $\mathrm{pH}$ to 7.0 .

\section{Extraction and Isolation}

The fermented whole broth (9.0 liters) was filtered through cheese cloth to separate into supernatant and mycelia. The mycelia was extracted three times with $\mathrm{Me}_{2} \mathrm{CO}$. The $\mathrm{Me}_{2} \mathrm{CO}$ solution was concentrated under reduced pressure to afford crude extract $(7.8 \mathrm{~g})$, showing strong cytotoxicity against the mouse $c d c 2$ mutant cell line (tsFT210, $\mathrm{IC}_{50}$ $68 \mu \mathrm{g} / \mathrm{ml}$ ) and antioxidation against 1,1-diphenyl-2pierylhydrazyl (DPPH, $\mathrm{IC}_{50} 98 \mu \mathrm{g} / \mathrm{ml}$ ). The crude extract was separated into 4 fractions on a silica gel column using a step gradient elution of $\mathrm{CHCl}_{3}-\mathrm{MeOH}$. The fraction $1(1.9 \mathrm{~g})$ was separated into 5 subfractions on a silica gel column using a step gradient elution of petroleum ether: $\mathrm{Me}_{2} \mathrm{CO}$. Subfraction 1-4 (73 mg) was crystallized from $\mathrm{CHCl}_{3} / \mathrm{MeOH}(\mathrm{v} / \mathrm{v} 9: 1)$ to yield 5 (39 mg). $9(11 \mathrm{mg})$ was isolated from the mother liquid of subfraction 1-4 by Sephadex LH-20 column (v/v 2: $1 \mathrm{CHCl}_{3} / \mathrm{MeOH}$ ). The fraction $3(0.8 \mathrm{~g})$ was subjected to column chromatography over silica gel (v/v 93:7 $\left.\mathrm{CHCl}_{3} / \mathrm{MeOH}\right)$ to afford 16 subfrations. Subfraction 3-2 (72 mg) was crystallized from $\mathrm{CHCl}_{3} / \mathrm{MeOH}(\mathrm{v} / \mathrm{v} 1: 1)$ to yield $8(59 \mathrm{mg})$. The mother liquid of subfraction 3-2, togather with the Fr. 3-3 and 3-4 were combined and subjected to HPLC separation (gradient elution of $70 \sim 100 \% \mathrm{MeOH})$ to yield $4(5.0 \mathrm{mg}), \mathbf{6}$ $(7.0 \mathrm{mg}), \mathbf{7}(9.0 \mathrm{mg}), \mathbf{1 0}(7.0 \mathrm{mg})$ and $\mathbf{1 1}(6.0 \mathrm{mg})$. The Fr. 3-7 (59 mg) was further separated by HPLC to yield 2 $(31 \mathrm{mg})$. Subfractions 3-14 $(29 \mathrm{mg})$ and 3-15 $(83 \mathrm{mg})$ were further separated by HPLC to yield $\mathbf{1}(15 \mathrm{mg})$ and $\mathbf{3}$ $(45 \mathrm{mg})$, respectively. Subfractions 3-5 and 3-6 were combined and subjected to HPLC to yield $\mathbf{1 2}(31 \mathrm{mg})$ and 13 (23 mg).

\section{Physico-chemical Analyses}

Optical rotations were obtained on a JASCO P-1020 digital polarimeter. UV spectra were recorded on Beckmen $\mathrm{DU}^{\mathbb{B}}$ 640 spectrophotometer. IR spectra were taken on a NICOLET NEXUS 470 spectrophotometer in $\mathrm{KBr}$ discs. ${ }^{1} \mathrm{H}-,{ }^{13} \mathrm{C}-\mathrm{NMR}$ and DEPT spectra and 2D-NMR were recorded on a JEOL JNM-ECP 600 spectrometer using TMS as internal standard and chemical shifts were recorded as $\delta$ values. ESI-MS was measured on a Q-TOF ULTIMA GLOBAL GAA076 LC mass spectrometer. Semipreparative HPLC was performed on a SHIMADZU LC-6AD Liquid Chromatograph with SPD-M10A vp Diode Array Detector.

\section{Biological Assay}

Cell lines were grown in RPMI-1640 supplemented with $10 \%$ FBS under a humidified atmosphere of $5.0 \% \mathrm{CO}_{2}$ and $95 \%$ air at $37^{\circ} \mathrm{C}$. Two hundred microliters of those cell suspensions at a density of $5 \times 10^{4} \mathrm{cell} / \mathrm{ml}$ was plated in 96 well microtiter plates and incubated for 24 hours at the above conditions. Then $2.0 \mu \mathrm{l}$ of the test compound solutions (in $\mathrm{MeOH}$ ) at different concentrations was added to each well and further incubated for 72 hours in the same conditions. Twenty microliters of the MTT solution $(5.0 \mathrm{mg} / \mathrm{ml}$ in RPMI-1640 medium) was added to each well and incubated for 4 hours. An old medium (150 $\mu \mathrm{l})$ containing MTT was then gently replaced by DMSO and pipetted to dissolve any formazan crystals formed. Absorbance was then determined on a SPECTRA MAX PLUS plate reader at $540 \mathrm{~nm}$.

In SRB assay, $200 \mu 1$ of the cell suspensions were plated 
Table $1{ }^{1} \mathrm{H}$ - and ${ }^{13} \mathrm{C}-\mathrm{NMR}$ data for variecolorquinone A (1) in DMSO- $d_{6}$

\begin{tabular}{|c|c|c|c|c|c|}
\hline No. & $\delta_{\mathrm{H}}(\mathrm{J}$ in $\mathrm{Hz})$ & $\delta_{\mathrm{C}}$ & No. & $\delta_{\mathrm{H}}(\mathrm{J}$ in $\mathrm{Hz})$ & $\delta_{\mathrm{C}}$ \\
\hline 1 & & $158.8 \mathrm{~s}$ & 10 & & $182.2 \mathrm{~s}$ \\
\hline 2 & & $129.4 \mathrm{~s}$ & $10 a$ & & $137.1 \mathrm{~s}$ \\
\hline 3 & & $143.3 \mathrm{~s}$ & $1-\mathrm{OH}$ & $13.6(\mathrm{~s})$ & \\
\hline 4 & 7.48 (s) & $119.6 d$ & $6-\mathrm{OH}$ & $11.3(\mathrm{~s})$ & \\
\hline $4 a$ & & $132.6 s$ & $3-\mathrm{CH}_{3}$ & $2.37(3 \mathrm{H}, \mathrm{s})$ & $19.9 q$ \\
\hline 5 & 7.19 (br s) & $107.1 d$ & $8-\mathrm{OCH}_{3}$ & $3.91(3 \mathrm{H}, \mathrm{s})$ & $56.8 q$ \\
\hline 6 & & $166.3 \mathrm{~s}$ & $1^{\prime}$ & & $164.0 \mathrm{~s}$ \\
\hline \multirow[t]{2}{*}{7} & 6.83 (br s) & $105.0 d$ & $2^{\prime}$ & $4.38(d d, 10.9,3.9)$ & $67.3 \mathrm{t}$ \\
\hline & & & & $4.19(\mathrm{dd}, 10.9,6.4)$ & \\
\hline 8 & & $165.2 \mathrm{~s}$ & $3^{\prime}$ & $3.76(\mathrm{~m})$ & $69.7 d$ \\
\hline \multirow[t]{2}{*}{$8 a$} & & 113.0s & $4^{\prime}$ & $3.43(\mathrm{dd}, 11.0,5.5)$ & $63.0 \mathrm{t}$ \\
\hline & & & & $3.38(d d, 11.0,6.2)$ & \\
\hline 9 & & $186.5 \mathrm{~s}$ & $3^{\prime}-\mathrm{OH}$ & $5.05(\mathrm{brs})$ & \\
\hline $9 a$ & & $115.1 \mathrm{~s}$ & $4^{\prime}-\mathrm{OH}$ & 4.75 (br s) & \\
\hline
\end{tabular}

Table $2{ }^{1} \mathrm{H}$ - and ${ }^{13} \mathrm{C}-\mathrm{NMR}$ data for variecolorquinone $\mathrm{B}(\mathbf{2})$ in $\mathrm{CDCl}_{3}$

\begin{tabular}{|c|c|c|c|c|}
\hline No. & $\delta_{\mathrm{H}}(\mathrm{J}$ in $\mathrm{Hz})$ & $\delta_{\mathrm{C}}$ & $\mathrm{HMBC}(\mathrm{H}-\mathrm{C})$ & ${ }^{1} \mathrm{H}-{ }^{1} \mathrm{H}$ COSY \\
\hline 1 & & 109.1s & & \\
\hline 2 & & $138.4 \mathrm{~s}$ & & \\
\hline 3 & $6.53(d, 1.3)$ & $125.4 d$ & $1,2,5$ & 5 \\
\hline 4 & & $146.1 \mathrm{~s}$ & & \\
\hline 5 & 6.78 (br s) & $117.7 d$ & 1, 3, 6, 4-Me & 3 \\
\hline 6 & & $163.6 \mathrm{~s}$ & & \\
\hline 7 & $4.00(2 \mathrm{H}, \mathrm{d}, 1.8)$ & $34.9 \mathrm{t}$ & $1,2,3,8,9,13$ & 13 \\
\hline 8 & & $147.7 \mathrm{~s}$ & & \\
\hline 9 & & $181.7 \mathrm{~s}$ & & \\
\hline 10 & & $158.6 \mathrm{~s}$ & & \\
\hline 11 & $5.87(d, 2.2)$ & $107.1 d$ & $9,10,12,13$ & 13 \\
\hline 12 & & $187.4 \mathrm{~s}$ & & \\
\hline 13 & $5.99(\mathrm{dt}, 1.8,2.2)$ & $132.7 d$ & $7,9,11$ & 7,11 \\
\hline 14 & & $170.8 \mathrm{~s}$ & & \\
\hline 4-Me & $2.32(3 \mathrm{H}, \mathrm{s})$ & $21.6 q$ & $3,4,5$ & \\
\hline 10-OMe & $3.85(3 \mathrm{H}, \mathrm{s})$ & $56.4 q$ & 10 & \\
\hline 14-OMe & $3.76(3 \mathrm{H}, \mathrm{s})$ & $52.2 q$ & 14 & \\
\hline 6-OH & $11.29(\mathrm{~s})$ & & $1,5,6$ & \\
\hline
\end{tabular}

in 96 -cell plates at a density of $2 \times 10^{5}$ cell $/ \mathrm{ml}$. Then $2.0 \mu \mathrm{l}$ of the test compound solutions (in $\mathrm{MeOH}$ ) at different concentrations was added to each well and the culture was further incubated for 24 hours. Following drug exposure, the cells were fixed with 12\% TCA and the cell layer was stained with $0.4 \%$ SRB. The absorbance of SRB solution was measured at $515 \mathrm{~nm}$. Dose response curves were generated and the $\mathrm{IC}_{50}$ values, the concentration of compound required to inhibit cell proliferation by $50 \%$, were calculated from the linear portion of log dose response curves.

In DPPH scavenging assay, $160 \mu \mathrm{l}$ of reaction mixtures containing test samples and $40 \mu \mathrm{M}$ DPPH (Sigma) dissolved in methanol were plated in 96-cell plates and kept in dark for 30 minutes. After the reaction, absorbance was then measured at $517 \mathrm{~nm}$, and percent inhibition was 


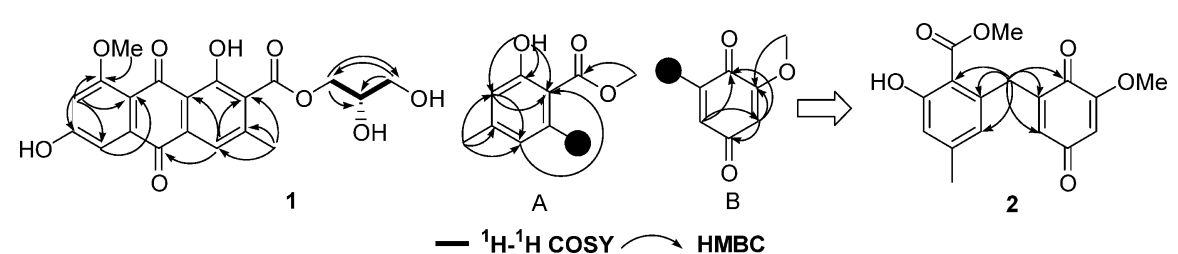

Fig. 2 The key HMBC and ${ }^{1} \mathrm{H}-{ }^{1} \mathrm{H}$ COSY correlations of $\mathbf{1}$ and $\mathbf{2}$.

calculated. $\mathrm{IC}_{50}$ values denote the concentration of sample required to scavenge $50 \%$ of the DPPH free radicals.

\section{Results and Discussion}

\section{Physico-chemical Properties}

1: yellow amorphous powder; $[\alpha]_{\mathrm{D}}^{25}-18(c 0.03 \mathrm{MeOH})$; HRESI-MS $m / z 401.0871$ (calcd for $\mathrm{C}_{20} \mathrm{H}_{17} \mathrm{O}_{9}, 401.0873$ ); UV $\lambda_{\max }^{\mathrm{MeOH}}(\log \varepsilon) \mathrm{nm} 223$ (4.1), 251 (3.8), 286 (3.9), 440 (3.5); IR $v_{\text {max }} \mathrm{cm}^{-1}$ (KBr) 3425, 2941, 1718, 1672, 1635, 1598, 1574, 1436, 1343, 1245, 1203, 1146, 1114, 1072, $1047,962,843 .{ }^{1} \mathrm{H}\left(\mathrm{DMSO}-d_{6}, 600 \mathrm{MHz}\right)$ and ${ }^{13} \mathrm{C}$ (DMSO$d_{6}, 150 \mathrm{MHz}$ ) see Table 1 .

2: yellow amorphous powder; HRESI-MS $\mathrm{m} / \mathrm{z} 315.0880$ (calcd for $\left.\mathrm{C}_{17} \mathrm{H}_{15} \mathrm{O}_{6}, 315.0869\right)$; UV $\lambda_{\max }^{\mathrm{MeOH}}(\log \varepsilon) \mathrm{nm} 197$ (4.2), 242 (4.1), 297 (3.9), 352 (3.7); IR $v_{\max } \mathrm{cm}^{-1}(\mathrm{KBr})$ $3068,1652,1602,1445,1326,1238,1177 .{ }^{1} \mathrm{H}\left(\mathrm{CDCl}_{3}\right.$, $600 \mathrm{MHz})$ and ${ }^{13} \mathrm{C}\left(\mathrm{CDCl}_{3}, 150 \mathrm{MHz}\right)$ see Table 2.

\section{Structure Determination}

1 was obtained as a yellow amorphous powder. Its molecular formula was determined as $\mathrm{C}_{20} \mathrm{H}_{18} \mathrm{O}_{9}$ based on HRESI-MS at $\mathrm{m} / z$ 401.0871 [M-H] $]^{-}$(calcd 401.0873). The diagnostic IR peaks were observed for hydroxyl and carbonyl at 3425 and $1718 \mathrm{~cm}^{-1}$, respectively. The UV spectra absorptions at $\lambda_{\max }(\log \varepsilon) 223$ (4.1), 251 (3.8), and 286 (3.9), 440 (3.5) suggested the presence of emodin skeleton in 1 [15]. Analysis of the 1D NMR spectra of 1 displayed three carbonyls, nine $s p^{2}$ quarternary carbons, three $s p^{2}$ methines, one oxygenated methine, two oxygenated methylenes, one methoxyl and one methyl (Table 1). Except for a methoxyl signal $\left(\delta_{\mathrm{H}} 3.91\right.$ and $\delta_{\mathrm{C}}$ $56.8)$ instead of hydroxyl signal $(\delta 12.72)$, the ${ }^{1} \mathrm{H}$ - and ${ }^{13} \mathrm{C}$ NMR spectra of $\mathbf{1}$ were similar to those of 3 [14], suggesting their structures were very similar. Further comparison of the ${ }^{13} \mathrm{C}-\mathrm{NMR}$ spectra of $\mathbf{1}$ with those of $\mathbf{3}$ revealed $-2.0,-3.1,-1.3,-4.9,+3.9$ and $+2.0 \mathrm{ppm}$ of chemical shift effects for C-5, C-7, C-8, C-9, C-8a and C$10 \mathrm{a}$, respectively, showing that $\mathbf{1}$ is 8 - $O$-methyl derivative of $\mathbf{3}$. This conclusion was further confirmed by key ${ }^{1} \mathrm{H}$ with ${ }^{13} \mathrm{C}$ long range correlations of $-\mathrm{OCH}_{3}$ with $\mathrm{C}-8, \mathrm{H}-5$ with
C-7 and C-8a, H-7 with C-5 and C-8a. The absolute configuration of C-2' was assigned as $S$ by comparing $[\alpha]_{\mathrm{D}}$ $\left(-18^{\circ}\right)$ with those of $3\left([\alpha]_{\mathrm{D}}-23^{\circ}\right)$ [14]. Thus, the structure of 1 was elucidated as (2S)-2,3-dihydroxypropyl1,6-dihydroxy-8-methoxy-3-methyl-9,10-dioxoanthracene2-carboxylate.

2 was obtained as yellow amorphous powder. Its molecular formula was determined as $\mathrm{C}_{17} \mathrm{H}_{16} \mathrm{O}_{6}$ based on

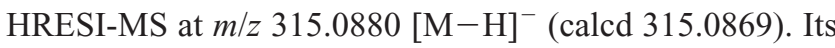
${ }^{1} \mathrm{H}$ spectral data revealed the signals of a hydrogen-bonded hydroxyl $\left(1-\mathrm{OH}, \delta_{\mathrm{H}} 11.29\right)$, two pairs of meta-coupled aromatic protons $\left(\delta_{\mathrm{H}} 6.53\right.$ and $6.78 ; 5.87$ and 5.99$)$, two methoxyls $\left(\delta_{\mathrm{H}} 3.76\right.$ and 3.85), an $s p^{3}$ methyl $\left(\delta_{\mathrm{H}} 2.32\right)$ and an $s p^{3}$ methylene $\left(\delta_{\mathrm{H}} 4.00\right)$. The ${ }^{13} \mathrm{C}$-NMR spectra of 2 contained three carbonyls, six $s p^{2}$ quaternary carbons including two oxygenated ones, four $s p^{2}$ methines, an $s p^{3}$ methylene, two methoxyls and a methyl (Table 1). According to 2D NMR spectrum, these protons and carbons were linked into two structural moieties, i.e. methyl 2-substituted-4-methyl-6-hydroxybenzoate and 2substituted-6-methoxybenzoquinone. These two moieties were further connected together via a methylene which was confirmed by HMBC correlations between $\mathrm{H}-7$ and C-1, C2, C-3, C-8, C-9 and C-13, and between $\mathrm{H}-13$ and C-7. These data are sufficient to assign the structure of $\mathbf{2}$ as methyl 2-hydroxy-6-[(5-methoxy-3,6-dioxocyclohexa-1,4dienyl)methyl]-4-methylbenzoate (Fig. 2).

\section{Cytotoxity and Radical Scavenging Activity}

The cytotoxicities of new compounds $\mathbf{1}$ and $\mathbf{2}$ were assayed in vitro against the P388 and HL-60 cell lines by the MTT method [18], and BEL-7402 and A-549 cell lines by the SRB method [19]. The $\mathrm{IC}_{50}$ values of $\mathbf{1}$ and $\mathbf{2}$ against P388, HL-60, BEL-7402 and A-549 cells were 266, 309, 114, 3.0 and $3.7,1.3,29$ and $56 \mu \mathrm{M}$, respectively. 1 selectively inhibited the proliferation of A-549 cell and 2 inhibited the proliferation of P388 and HL-60 cells. 1, 2, 12 and $\mathbf{1 3}$ were also evaluated for their radical scavenging activity against DPPH [20]. 1 showed moderate activity with $\mathrm{IC}_{50}$ values of $28 \mu \mathrm{M}$, while 2 was inactive $\left(\mathrm{IC}_{50}>100 \mu \mathrm{M}\right) .12$ and $\mathbf{1 3}$ which were strong KDR kinase inhibitors [17] exhibited strong antioxidative activity against $\mathrm{DPPH}$ with $\mathrm{IC}_{50}$ values 
of $6.0 \mu \mathrm{M}$ and $11 \mu \mathrm{M}$, respectively (ascorbic acid as positive control, $\mathrm{IC}_{50} 22 \mu \mathrm{M}$ ).

Acknowledgement This work was supported by the Chinese National Natural Science Fund (No. 30470196 and 30670219). The fungus strain $A$. variecolor B-17 was identified by Prof. Li Tian (First Institute of Oceanography, State Oceanic Administration of China). The cytotoxicity assay was performed at the Shanghai Institute of Materia Medica, Chinese Academy of Sciences.

\section{References}

1. Bugni TS, Ireland CM. Marine-derived fungi: a chemically and biologically diverse group of microorganisms. Nat Prod Rep 21: 143-163 (2004)

2. Masuma R, Yamaguchi Y, Noumi M, Omura S, Michio N. Effect of sea water concentration on hyphal growth and antimicrobial metabolite production in marine fungi. Mycoscience 42: 455-459 (2001)

3. Kogej T, Ramos J, Plemenitas A, Gunde-Cimerman N. The halophilic fungus Hortaea werneckii and the halotolerant fungus Aureobasidium pullulans maintain low intracellular cation concentrations in hypersaline environments. Appl Environ Microb 71: 6600-6605 (2005)

4. Turk M, Mejanelle L, Sentjurc M, Grimalt JO, GundeCimerman N, Plemenitas A. Salt-induced changes in lipid composition and membrane fluidity of halophilic yeast-like melanized fungi. Extremophiles 8: 53-61 (2004)

5. Larsen TO, Smedsgaard J, Nielsen KF, Hansen ME, Frisvad JC. Phenotypic taxonomy and metabolite profiling in microbial drug discovery. Nat Prod Rep 22: 672-695 (2005)

6. Liu W, Gu Q, Zhu W, Cui C, Fan G. Dihydrotrichodimerol and tetrahydrotrichodimerol, two new bisorbicillinoids, from a marine-derived Penicillium terrestre. J Antibiot 58: 621-624 (2005)

7. Liu W, Gu Q, Zhu W, Cui C, Fan G. Two new benzoquinone derivatives and two new bisorbicillinoids were isolated from a marine-derived fungus Penicillium terrestre. J Antibiot 58: 441-446 (2005)

8. Liu W, Gu Q, Zhu W, Cui C, Fan G, Zhu T, Liu H, Fang Y. Penicillones $\mathrm{A}$ and $\mathrm{B}$, two novel polyketides with tricyclo [5.3.1. $\left.0^{3,8}\right]$ undecane skeleton, from a marine-derived fungus Penicillium terrestre. Tetrahedron Lett 46: 4993-4996
(2005)

9. Ren H, Tian L, Gu Q, Zhu W. Secalonic acid D; a cytotoxic constituent from marine lichen-derived fungus Gliocladium sp. T31. Arch Pharm Res 29: 59-63 (2006)

10. Liu R, Zhu W, Zhang Z, Zhu T, Liu H, Fang Y, Gu Q. A new diphenyl ether from marine-derived fungus Aspergillus sp. B-F-2. J Antibiot 59: 362-365 (2006)

11. Liu R, Gu Q, Zhu W, Cui C, Fan G, Fang Y, Zhu T, Liu H. 10-Phenyl-[12]-cytochalasins Z7, Z8, and Z9 from the marine-derived fungus Spicaria elegans. J Nat Prod 69: 871-875 (2006)

12. Du L, Zhu T, Fang Y, Liu H, Gu Q, Zhu W. Aspergiolide A, a novel anthraquinone derivative with naphtho[1,2,3de]chromene-2,7-dione skeleton isolated from a marinederived fungus Aspergillus glaucus. Tetrahedron 63: 1085-1088 (2007)

13. Zhang Y, Zhu T, Fang Y, Liu H, Gu Q, Zhu W. Carbonarones $\mathrm{A}$ and $\mathrm{B}$, new bioactive $\gamma$-pyrone and $\alpha$-pyridone derivatives from the marine-derived fungus Aspergillus carbonarius. J Antibiot 60: 153-157 (2007)

14. Segaw A, Miyaichi Y, Tomimori T, Kiuchi F, Ohta T. Studies on nepalese crude drugs XXV. Phenolic constituents of the leaves of Didymocarpus leucocalyx C. B. Clarke (Gesnerriaceae). Chem Pharm Bull 47: 1404-1411 (1999)

15. Kalidhar SB. Structural elucidation in anthraquinones using proton NMR glycosylation and alkylation shifts. Phytochemistry 28: 3459-3463 (1989)

16. Anke H, Kolthoum I, Laatsch H. Metabolic products of microorganisms. 192. The anthraquinones of the Aspergillus glaucus group. II. Biological activity. Arch Microbiol 126: 231-236 (1980)

17. Eder C, Kogler H, Toti L. Preparation of eurotinone, a KDR kinase inhibitor from Eurotium echinulatum (DSM 13872). WO 2003002549 (2003)

18. Skechan P, Storeng R, Scudiero D, Monks A, Mcmahon J, Vistica D, Warren JT, Bokesch H, Kenney S, Boyd MR. New colorimetric cytotoxicity assay for anticancer-drug screening. J Natl Cancer Inst 82: 1107-1112 (1990)

19. Mosmann T. Rapid colorimetric assay for cellular growth and survival: application to proliferation and cytotoxicity assay. J Immunol Methods 65: 55-63 (1983)

20. Chen Y, Wong M, Rosen RT, Ho CT. 2,2-Diphenyl-1picrylhydrazyl radical-scavenging active components from Polygonum multiflorum Thunb. J Agric Food. Chem 47: 2226-2228 (1999) 